University of Michigan Law School

University of Michigan Law School Scholarship Repository

\title{
Making Something Out of Nothing: The Law of Takings and Phillips v. Washington Legal Foundation
}

\author{
Michael A. Heller \\ University of Michigan Law School, mhelle@law.columbia.edu \\ James E. Krier \\ University of Michigan Law School, jkrier@umich.edu
}

Available at: https://repository.law.umich.edu/articles/578

Follow this and additional works at: https://repository.law.umich.edu/articles

Part of the Constitutional Law Commons, Property Law and Real Estate Commons, Public Law and Legal Theory Commons, and the Supreme Court of the United States Commons

\section{Recommended Citation}

Krier, James E. "Making Something Out of Nothing: The Law of Takings and Phillips v. Washington Legal Foundation." M. Heller, co-author. Sup. Ct. Econ. Rev. 7 (1999): 285-301.

This Article is brought to you for free and open access by the Faculty Scholarship at University of Michigan Law School Scholarship Repository. It has been accepted for inclusion in Articles by an authorized administrator of University of Michigan Law School Scholarship Repository. For more information, please contact mlaw.repository@umich.edu. 


\title{
Making Something Out of Nothing: The Law of Takings and Phillips $v$. Washington Legal Foundation
}

\author{
Michael A. Heller \& James E. Krier†
}

Phillips v. Washington Legal Foundation held that interest on principal amounts deposited into IOLTA accounts is the property of the various clients who handed over the money but expressed no view as to whether the Texas IOLTA program worked a taking, or, if it did, whether any compensation was due. The debates among the justices about the meaning of private property, argued in terms of contextual and conceptual severance, are unlikely to prove fruitful. We elaborate a better approach in terms of the underlying purposes of just compensation. We conclude that efficiency and justice are best served by uncoupling matters and methods of deterrence from matters and methods of distribution.

\section{N T RODUCTION}

Phillips v. Washington Legal Foundation, ${ }^{1}$ recently decided by a divided Supreme Court, involved the meaning of the words "private property" in the Constitution's injunction, "nor shall private property be taken for public use, without just compensation." ${ }^{\prime 2}$ Against the urgings of several dissenting opinions, the majority approached and settled the property issue in a way that left the application of

† Assistant Professor and Earl Warren DeLano Professor, University of Michigan Law School.

1118 S Ct 1925 (1998).

${ }^{2}$ US Const, Amend V (ratified 1791). The Fifth Amendment is made applicable to the states through the Fourteenth Amendment. Chicago, $B \oplus Q R$ Co $v$ Chicago, 166 US 226, 239 (1897).

(C) 1999 by Michael A. Heller and James E. Krier. All rights reserved. 0-226-14288-4/99/0007$0006 \$ 02.00$ 
the rest of the Takings Clause to be resolved on remand. The case has provoked us to think anew about takings law, and to consider, in that light, how the issues remaining in Phillips should be resolved.

\section{THE BACKGROUND OF PHILLIPS}

For generations, law professors and their students have pondered the question, "What is private property"? The same issue is obviously latent in every takings dispute, but seldom aired in any because the "property-ness" of the asset at stake in the litigation is usually uncontested. In Phillips, it was not.

Behind the case are the trust accounts that lawyers maintain for client funds. ${ }^{3}$ A lawyer who holds funds for any one client in an amount sufficient to earn interest net of banking, accounting, and tax reporting expenses usually puts the money in a separate interestbearing account on the client's behalf. Often, though, client funds are too nominal in amount, or held for too short a time, to earn net interest. Prior to 1980, lawyers usually pooled funds of this sort in federally insured checking accounts which, thanks to banking regulations, could not pay any interest. (In other words, the float on the accounts went to the banks.) In 1980, Congress changed the rules and allowed federally insured banks to offer individuals and certain charitable organizations a form of interest-bearing checking account. ${ }^{4}$ The Federal Reserve Board then ruled that corporate and partnership funds could be deposited in trust into such accounts if charitable organizations received the interest. ${ }^{5}$ Finally, the Internal Revenue Service took the position that interest on lawyer trust accounts need not be treated as taxable client income if clients could not participate in selecting the charitable organizations that were to receive the interest. ${ }^{6}$

\footnotetext{
${ }^{3}$ Our brief summary of the facts underlying Phillips is mostly drawn from the majority opinion, $118 \mathrm{~S} \mathrm{Ct}$ at 1928-29.

${ }^{4}$ See Consumer Checking Account Equity Act of 1980 (Title III of the Depository Institutions Deregulation and Monetary Control Act of 1980), Pub L No 96-221 § 303, 94 Stat 146 (1980), codified at 12 USC $§ 1832$ (a) (1994), 12 CFR $\S 204.130$ (1997).

${ }^{5}$ See 118 S Ct at 1928, citing Letter from Federal Reserve Board General Counsel Michael Bradfield to Donald Middlebrooks (Oct 15, 1981) reprinted in Donald Middlebrooks, The Interest on Trust Accounts Program: Mechanics of its Operation, 56 Fla BJ 115, 117 (1982). Corporations and partnerships cannot benefit from some features of pooling because banking regulations prohibit them from using interest-bearing checking accounts (though if the amounts were sufficient, corporate trust funds would be held in interest-bearing savings accounts on the client's behalf). See Transcript of Oral Argument, 1998 WL 13590, at " 4 ("Transcript") (noting that about $60 \%$ of Texas IOLTA income came from interest on corporate and partnership deposits).

${ }^{6}$ See Rev Rul 81-209, 1981-2 C B 16; Rev Rul 87-2, 1987-1 C B 18.
} 
Shortly after these changes in the background legal rules, every state and the District of Columbia began enacting Interest on Lawyers Trust Account (IOLTA) programs ${ }^{7}$ to capture the net interest that could be earned on nominal and short-term client funds. ${ }^{8}$ Four states now have "voluntary" IOLTA programs in which each lawyer may decide whether to participate, twenty have programs in which a lawyer may "opt-out" by advising the state IOLTA agency, and twenty-seven have "mandatory" programs in which all lawyers must participate. ${ }^{9}$ Each state program creates a nonprofit umbrella organization to receive IOLTA funds and distribute them in support of legal services for the poor. By pooling nominal and short-term client funds that previously went as interest-free loans to banks, IOLTA programs are able to generate $\$ 100$ million a year for legal service organizations nationwide.

The central question in Phillips-and the only issue that ultimately reached the Supreme Court-had to do with the status of IOLTA interest earned on funds deposited in Texas' mandatory IOLTA program. The plaintiffs claimed that, at least for purposes of the Takings Clause, the interest was the property of the clients who indisputably owned the underlying principal, but the district court disagreed. ${ }^{10}$ Since the money deposited in IOLTA accounts would not have earned any interest at all if deposited elsewhere, the clients really lost nothing. They never had any property in the interest; hence nothing of theirs was taken. ${ }^{11}$ Similar reasoning had probably persuaded the hundreds of judges around the country who voted to

${ }^{7}$ The IOLTA concept originated in Australia, spread to Canada, then to the United States. See Arthur J. England, Jr. \& Russell E. Carlisle, History of Interest on Trust Accounts Program, 56 Fla BJ 101 (1982).

${ }^{8}$ At oral argument in the Phillips case, lawyers for Texas noted that, "[i]t is only the funds that are incapable, whether using technology, subaccounting, pooling, or whatever, that can not yield a net benefit to a client, that go into IOLTA." Transcript at *8-* (cited in note 5); see also $118 \mathrm{~S} \mathrm{Ct}$ at 1932 . Some states have incorporated thresholds into their IOLTA rules such that client funds cannot be considered nominal or short term if lawyers expect the funds to earn interest of more than $\$ 50 . A B A$ / BNA Lawyers' Manual on Professional Conduct $\S 904: 4707$ (1990). If lawyers guess wrong and client funds earn more than anticipated, then the funds are expected to be transferred retroactively out of the IOLTA program and to the client. Id at $\S 901: 4602$ (1987).

${ }^{9}$ Id at $\S$ 45:202-05 (1997).

${ }^{10}$ Washington Legal Foundation v Texas Equal Access to Justice Foundation, 873 F Supp 1 (WD Tex 1995).

${ }^{11}$ Id at 7 . The court's logic led it to reject as well a related claim that the Texas IOLTA program deprived clients of First Amendment rights of freedom of speech and association by forcing them "to financially support, and thereby associate with, various recipient organizations whose purported objectives [they] find objectionable." 
adopt IOLTA programs in their states, ${ }^{12}$ just as it figured in two earlier cases decided by federal courts of appeals. ${ }^{13}$

But the Court of Appeals for the Fifth Circuit thought otherwise. ${ }^{14}$ Obviously, the funds deposited into IOLTA accounts belonged to the clients, and this meant that the clients owned the amounts earned by the funds as well, because under the applicable Texas law "interest follows principal." Justice Rehnquist, affirmed the proposition that IOLTA interest is the clients' property, but left open the questions whether that property had been taken, and, if it had, whether just compensation had to be paid. ${ }^{16}$ Those were matters to be decided on remand. ${ }^{17}$ Four justices dissented in two separate opinions. ${ }^{18}$

\section{THE OPINIONS IN PHILLIPS}

So, what is property? Law teachers particularly like the question because they know, and want their students to see, that it cannot be answered by a priori reasoning. True, Blackstone referred to property as "that sole and despotic dominion which one man claims and exercises over the external things of the world, in total exclusion of the right of any other individual in the universe, ${ }^{\prime \prime 19}$ and this does seem to say something, but only at first. The statement leaves open

Id at 9. The court ruled as it did in part because "at least as far as the client is concerned, such a claim is necessarily predicated upon the Plaintiffs' claim that the funds generated from the IOLTA accounts are, in fact, the property of the client." Id at 9 .

${ }^{12}$ The highest courts of seven states have held that IOLTA programs do not work a taking. Another thirty-seven state supreme courts including Texas used their rulemaking authority to adopt IOLTA programs, while five states adopted the programs by legislation. See Brief of Amici Curiae Alabama Law Foundation, Inc. et al. in Support of Petitioners, Phillips, 118 S Ct 1925 (No. 96-1578) available in 1997 WL 476500 , at ${ }^{*} 12-{ }^{*} 13$. See also ABA Comm on Ethics and Prof Responsibility, Formal Opinion 348 (July 23, 1982) (endorsing ethical propriety of IOLTA programs).

${ }^{13}$ Washington Legal Foundation v Massachusetts Bar Foundation, 993 F2d 962 (1st Cir 1993) (upholding program against a challenge by the same public interest law foundation that brought Phillips); Cone v State Bar of Fla, 819 F2d 1002 (11 th Cir), cert. denied, 487 US 917 (1987) (upholding IOLTA program in a case where client

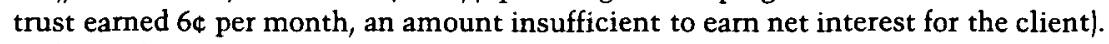

${ }^{14}$ Washington Legal Foundation v Texas Equal Access to Justice Foundation, 94 F3d 996 (5th Cir 1996).

${ }^{15}$ Id at 1004.

${ }^{16}$ Phillips, $118 \mathrm{~S} \mathrm{Ct}$ at 1934.

17 Id.

${ }^{18}$ See id (Souter, J, dissenting, joined by Justices Stevens, Ginsburg and Breyer) and id at 1937 (Breyer, J, dissenting, joined by Justices Stevens, Souter and Ginsburg).

${ }^{19} 2$ William Blackstone, Commentaries * 2 . 
the questions of just when that dominion is recognized, and just how extensive it is. Blackstone himself acknowledged and discussed many limitations on property ownership and understood that property had come to be a creature of the system. Bentham, writing not all that much later, made the last point explicit by defining property as "a basis of expectation; the expectation of deriving certain advantages from a thing," and that expectation "can only be the work of law." ${ }^{20}$ Property "is not material, it is metaphysical; it is a mere conception of the mind, ${ }^{\prime 21}$ what others have called "a euphonious collocation of letters which serves as a general term for the miscellany of equities that persons hold in the commonwealth." ${ }^{\prime 22}$

From this little discussion, we can see plainly the problem facing the Court in Phillips, or facing any authoritative lawmaker confronted by the question, "What is private property?": If the Court were to say that the interest in IOLTA accounts is private property, then private property it would be; otherwise not. The resulting circularity can be avoided, so far as we can see, by at least two methods. As it happens, Chief Justice Rehnquist (for the majority) adopted the first, and Justice Souter (dissenting) the second. So let us examine each method in turn.

\section{A. Method One: "Private Property" in Isolation}

The method here is to confront the what-is-private-property question in isolation from the other operative words of the Takings Clause and then pass the buck to somebody else, because, as we have seen, the question cannot readily be resolved without respect to context. The majority opinion had grounds for following this segmented approach. First, the Takings Clause contains the crucial words "private property" and "taken" and "just compensation," and it seems straightforward enough to consider what each of these terms means in its turn, without regard to the other terms. ${ }^{23}$ Second, as to the meaning of private property, the Constitution is thought to protect property rights that are themselves determined by reference to

${ }^{20} 1$ Jeremy Bentham, Theory of Legislation 137 (1840).

${ }^{21}$ Id.

${ }^{22}$ Walton Hamilton \& Irene Till, Property, in 12 Encyclopedia of the Social Sciences 528 (1934).

${ }^{23}$ The clause mentions "public use" too, but this requirement was not an issue in Phillips and is pretty much a throw-away in any event, at least in the federal courts. See Jesse Dukeminier \& James E. Krier, Property 1112-16, 1214-15 (Aspen, 4th ed 1998) (discussing "public use"). Oddly, the remaining words of the Takings Clause, "nor" "shall" "be" "for" and "without," seem to have attracted little if any analytical attention. 
"existing rules or understandings that stem from an independent source such as state law. ${ }^{\prime 24}$ This view left the Court free to pass the buck to Texas, relying-as had the court of appeals-on the Texas rule that "interest follows principal." 25 Texas, of course, had done the same thing much earlier on, looking to English common law to find the maxim about interest. And the English judges themselves had never really thought the matter through either; they simply figured that interest follows principal "as the shadow [does] the body."26 But this was enough for the majority in Phillips, which quickly moved from affirming the Texas rule to dismissing several other assertions on the property issue that had been urged upon the Court. $^{27}$

\section{B. Method Two: "Private Property" in Context}

As we noted earlier, the Court's decision in Phillips did not dispose of the case, but only of the private property issue. As a result of the majority's method, there remained the questions whether private property had been "taken" and whether and what "just compensation" might be due. These the Court remanded as distinct inquiries, separate from the one about "private property."

The dissenters, in contrast, thought that all three questions should be decided, sensibly could only be decided, as integral parts of a single inquiry that focused not on the meaning of property in isolation, but rather "only in connection with what is a compensable

${ }^{24}$ Board of Regents of State Colleges v Roth, 408 US 564, 577 (1972), quoted in Phillips, $118 \mathrm{~S} \mathrm{Ct}$ at 1930.

${ }^{25}$ The Court held that examples in Texas law where interest does not follow principal were "insufficient to dispel the presumption of deference given the views of a federal court as to the law of a State within its jurisdiction." Phillips, $118 \mathrm{~S} \mathrm{Ct}$ at 1931. That "two of the three judges" on the court of appeals panel were Texans, id, seems to have outweighed the inclinations of the Texas Supreme Court (petitioners Phillips and the "et al" in the case title include the Court's justices) on this aspect of Texas law.

${ }^{26}$ Beckford v Tobin, 27 Eng Reg 1049, 1051 (Ch 1749), quoted in Phillips, $118 \mathrm{~S}$ $\mathrm{Ct}$ at 1930. In criticizing this reasoning, Justice Breyer wrote, "The slogan interest follows principal no more answers that question than does King Diarmed's legendary slogan, To every cow her calf." Id at 1938 (Breyer, J., dissenting) (internal quotation marks omitted).

${ }^{27}$ The Court observed that "property is more than economic value," so even if the value of the interest at stake were equal to zero, the property right in that interest might still be deserving of constitutional protection, though how it would be protected is unclear. Id at 1933. Finally, the Court countered arguments that the government created the value by noting that it is the lawyers who pooled the funds. Id at 1933 . 
taking, ${ }^{\prime 28}$ as Justice Souter put it. By addressing the property issue on its own, he argued, the Court had ignored "the most salient fact" in the case, that the client asserting a taking could never have received net interest, thanks to the combination of federal and state regulatory provisions that we described earlier. ${ }^{29}$ Those provisions obviously related to the takings and just compensation issues, but they were "relevant to the property issue as well, simply because the way we may ultimately resolve the taking and compensation issues bears on the way we ought to resolve the property issue. ${ }^{\prime \prime 30}$ It could turn out that the regulatory structure did not effect a taking, or that the just compensation for any taking was zero. In that event, "recognizing a client's property right in the interest ... would be an inconsequential abstraction. ${ }^{\prime \prime 31}$ Accordingly, the best method is "to consider what is property only in connection with what is a compensable taking. ${ }^{.32}$ Since the court of appeals had done otherwise, the case should have been sent back to it for application of the correct approach. ${ }^{33}$

\section{Does Method Matter?}

One of the interpretive moves dividing the majority and dissenters in Phillips can be called "contextual severance," a phrase we coin in order to echo the familiar problem of "conceptual severance" in takings law. ${ }^{34}$ The majority adopted exactly the method the dissenters opposed, a clause-chopping strategy for reading the Takings

${ }^{28}$ Id at 1935 (Souter, I., dissenting).

${ }^{29}$ Id at 1934. See text accompanying notes 4-6 (describing the relevant regulations).

${ }^{30}$ Id at 1935.

${ }^{31} \mathrm{Id}$, citing and quoting Hooker v Burr, 194 US 415,419 (1904) ("If a contractual obligation is impaired, but the obligor is 'not injured to the extent of a penny thereby, his abstract rights are unimportant ${ }^{\prime \prime}$ ).

${ }^{32}$ Id at 1935.

${ }^{33} \mathrm{Id}$ at 1937. In the other dissenting opinion in Phillips, Justice Breyer expressed agreement with Justice Souter's views but went on to say that, if one accepted the "property in isolation" method for the sake of argument, then the majority had its substantive conclusions wrong. Id at 1938-39 (Breyer, I, dissenting). Justice Souter agreed.

${ }^{34}$ Conceptual severance refers to the problem of identifying the relevant property for constitutional analysis, in this case whether the IOLTA interest is a discrete piece of property that was wholly taken, or a part of a larger principal that was reasonably regulated. See Margaret Jane Radin, The Liberal Conception of Property: Cross Currents in the Jurisprudence of Takings, 88 Colum L Rev 1667, 1676 (1988) (defining conceptual severance). See also Frank Michelman, Takings, 1987, 88 Colum L Rev 1600,1601 (1988) (noting that conceptual severance might also be called "entitlement chopping"l. 
Clause that severs each operative term from all the others in searching for the meaning of constitutional language. But the ultimate result in Phillips is unlikely to turn on the majority's interpretive triumph. After all, nothing in the majority's approach-each issue of itself, seriatim-dictates that a taking will be found, or, if one is, that compensation will be awarded, just as nothing in the views of the dissenters-the issues integrated, everything of a piecenecessarily forecloses such results. Notice also that one cannot even say which approach generally economizes on the time and expense of litigation. The majority's seriatim approach ends up doing so whenever a court finds there is no private property interest, because in that event the court can avoid other issues (is there a taking? what is just compensation?). On the other hand, Justice Souter's integrated method saves time if, but only if, it turns out that every issue has to be confronted..$^{35}$

The justices did more than debate the merits of contextual severance; they also rehearsed the conceptual severance issue bound to arise on remand. The majority severed the IOLTA interest from its principal. "As to principal," the Chief Justice wrote in his opinion for the Court, "the IOLTA rules at most "regulate[] the use of [the] property, ${ }^{\prime \prime 36}$ presumably to an insufficient degree to give rise to a taking. The interest, on the other hand, was a separate thing-indeed, a real thing that "follows principal" the way a duckling follows its mother duck - to be regarded as discrete "private property" for purposes of takings analysis. Never mind that the interest had no value. "We have never held that a physical item is not 'property' simply because it lacks a positive economic or market value." ${ }^{\prime 37}$

In his dissenting opinion, Justice Souter adamantly rejected conceptual severance. "With its narrow focus on a party's right to any interest generated by its principal, the Court's opinion might be read (albeit erroneously, in my view) to mean that the accrued interest is the only property right relevant to the question whether IOLTA

${ }^{35}$ Justice Souter was concerned to "avoid spending time on what might turn out to be an entirely theoretical matter." Phillips, $118 \mathrm{~S} \mathrm{Ct}$ at 1935 . But he overlooked the fact that the seriatim approach actually saves time in any instance where it leads to a conclusion that no "private property" interest is at stake, just the result Justice Breyer would have reached.

${ }^{36}$ Id at 1930, quoting Yee v Escondido, 503 US 519, 522 (1992).

${ }^{37}$ Id at 1933. The Court's usage is confusing because zero interest is not, by any stretch of the imagination, "a physical item." The confusion is compounded by what the Court went on to say: "While the interest income at issue here may have no economically realizable value to its owner, possession, control, and disposition are nonetheless valuable rights that inhere in the property." Id at 1933. How does one possess, control, and dispose of nothing? 
effects a taking. ${ }^{\prime \prime 38}$ Rather, he said, the takings analysis should consider the principal and interest as a whole. Justice Breyer (also dissenting) agreed, but considered, for the sake of argument, whether the severed interest is private property. He concluded that it is not. Even if a separate and discrete real thing, IOLTA interest is not the property of the owner of the principal under his reading of the selected truisms, Supreme Court precedents, and Texas law..$^{39}$

In short, the members of the Court argued about three different conceptions: sever IOLTA interest and call it property (the majority); forbear from severing the interest from its principal (Souter); sever the interest and still it is not property (Breyer). We prefer a different approach, one concerned far less with the meaning of "private property" and far more with the ethical and economic concerns underlying the Takings Clause.

\section{AN EXPANDED APPROACH TO THE LAW OF TAKINGS}

To begin, notice that there is one interesting matter on which all the justices in Phillips agreed. Recall that the majority concluded that IOLTA interest is client property but did not decide whether that property had been taken, or whether, even if it had, any compensation was due. The dissenters, for their part, considered that the majority's resolution of the property issue was little more than an academic exercise, because even if the interest had been taken, just compensation would most likely amount to zero. ${ }^{40}$ So the majority and dissenters actually shared the view that there can be a taking without compensation, their consensus in this respect probably owing to the strange combination of circumstances behind IOLTA programs. The measure of just compensation in takings case is usually figured with reference to what the aggrieved claimants have lost. ${ }^{41}$ Arguably that was nothing because the interest generated

${ }^{38}$ Id at 1935 n.3 (Souter, J, dissenting).

${ }^{39}$ Id at 1938-39 (Breyer, J, dissenting).

${ }^{40}$ See Part II above (describing the views of the majority and the dissenters). The majority's precise words were: "We express no view as to whether these funds have been 'taken' by the State; nor do we express an opinion as to the amount of 'just compensation,' if any, due respondents." Phillips, $118 \mathrm{~S} \mathrm{Ct}$ at 1934. Justice Souter said much the same for the dissenters: it could "turn out that ... the IOLTA scheme had not taken the property recognized today, or ... that the 'just compensation' for any taking was zero." Id at 1935.

${ }^{41}$ See, for example, id at 1936 (Souter, J, dissenting) (noting compensation measured by claimant's loss, not by government's or public's gain). 
by IOLTA programs would not have been earned by the aggrieved claimants in any event.

In that sense, the idea of a taking without compensation is utterly conventional. But in another sense it is not. Phillips provoked us to think more generally about the virtues of uncoupling "taking" on the one hand from "compensation" on the other. The exercise resulted in an expanded conception of takings law that we have explained at some length elsewhere. ${ }^{42}$ Here we shall sketch the approach in just enough detail to permit some thoughts about its bearing on Phillips.

We begin with the purposes underlying the Takings Clause, which everyone seems to agree are efficiency on the one hand and justice on the other. ${ }^{43}$ We find it useful to think about these two objectives in terms of deterrence and distribution, respectively. The obligation to pay compensation for the taking of property aims to promote efficiency by deterring governmental agencies from undertaking regulatory moves that are not worth their social cost. The obligation to pay brings the price system into play and thus helps shape appropriate incentives. The larger the burden imposed on property owners by some regulatory program, the greater the case for government liability with respect to those burdens, in order to promote what we call general deterrence. Specific deterrence has the related but somewhat different objective of using the obligation to pay as a means of thwarting government efforts to promote the public good at the expense of politically vulnerable groups and individuals. ${ }^{44}$

Turn now from efficiency and deterrence to distributional justice, the second concern of the Takings Clause. The idea here is to spread the costs of regulatory programs widely rather than having them fall unfairly on a relatively few owners of property. As Justice Black put it in a well-known statement: "The Fifth Amendment's guarantee

${ }^{42}$ See Michael A. Heller \& James E. Krier, Deterrence and Distribution in the Law of Takings, 112 Harv L Rev 997 (1999) ("Heller \& Krier, Deterrence"). Our development and application of uncoupling in the takings context is entirely novel, but the general idea of separating two things ordinarily tied together has appeared before in the case law and in the literature. See, for example, BMW of North America $v$ Gore, 517 US 559, 614-18 (1996) (Ginsburg, J, dissenting) (Appendix to Opinion) (noting the thirteen states that require payment of a portion of punitive damage awards to state agencies rather than to plaintiffs); A. Mitchell Polinsky, Detrebling versus Decoupling Antitrust Damages: Lessons from the Theory of Enforcement, 74 Geo LJ 1231 (1986) (discussing idea of uncoupling amount of antitrust damages paid by defendant from amount of damages paid to plaintiff).

${ }^{43}$ The classic discussion is Frank I. Michelman, Property, Utility, and Fairness: Comments on the Ethical Foundations of "Just Compensation" Law, 80 Harv L Rev 1165 (1967).

${ }^{44}$ See, e.g., Daniel A. Farber, Economic Analysis and Just Compensation, 12 Int'l Rev L \& Econ 125 (1992). 
that private property shall not be taken for a public use without just compensation was designed to bar Government from forcing some people alone to bear public burdens which, in all fairness and justice, should be borne by the public as a whole. ${ }^{\prime \prime 4}$

Regarding distribution, it proves useful once again to contrast the specific to the general. Specific distribution is a term we coin to describe the conventional method of compensation that courts use in takings cases now. Losses are determined and distributed on an individual basis; each property owner receives a payment specifically tailored to compensate for the reduction in value of his or her property. General distribution, something of our own invention, would work very differently. The government would be required to pay, but the amount due would be calculated by aggregating average individual losses. The resulting total would not be handed over to individual owners but instead deposited into a special fund, into general revenues, or even rebated to taxpayers. (We shall discuss fruitful variations on this approach later in connection with Phillips.) For general distributions to work effectively the relevant intergovernmental fiscal boundaries must not be too porous, else damage payments could flow back to the responsible government bureau and undermine the intended deterrent effect. ${ }^{46}$ Legislative bodies would have to resist any temptation simply to make an agency whole again in the next round of the budgetary process. Given that agencies compete for funds, they should be eager to police the appropriation process in this regard.

To illustrate the virtues of general distribution, consider the not unusual case where a government regulatory program imposes small costs on a very large number of property owners. Because the costs may be large in the aggregate, general deterrence becomes a concern. At the same time, however, the large number of aggrieved owners means that the transaction costs of figuring out and compensating for losses on an individual basis by way of a specific distribution are likely to be high enough to swamp whatever net social benefits might otherwise flow from the government program in question. Here the conventional law forces us to a difficult choice: If we say there is no taking, then the government pays nothing when deterrence might call for it to pay something. And if we say there is a taking, then potentially beneficial programs might be abandoned, or

${ }^{45}$ Armstrong v United States, 364 US 40, 49 (1960).

${ }^{46}$ See Richard A. Posner, Economic Analysis of Law 64 (Aspen, 5th ed 1998) (noting how hard budget constraints can discipline public officials). Another approach could be to require that a general distribution take the form of a tax refund or cut. 
pursued at a net loss, because the high transaction costs of making conventional specific distributions will wipe out any social gains.

By inventing the mechanism of general distribution, we make the difficult choice unnecessary. We can for the sake of deterrence charge the responsible government agency, yet at the same time reduce transaction costs dramatically by figuring compensation only on an average basis, and distributing it generally rather than specifically. So long as justice does not call for individual payments, the method can resolve the tensions inherent in the conventional approach to takings.

The short of it is this. Conventional takings law couples together matters that should be treated independently. Cases are resolved by holding either that there is a taking and compensation is due or that there is no taking and no compensation is due. This is fine enough when one or the other result harmoniously serves the dual purposes of the Takings Clause-efficiency and justice or, in our terms, deterrence and distribution. Commonly, however, the two purposes come into conflict. To deal with such situations, we need two more possible case resolutions. One would allow the courts to find a taking, for the sake of deterrence, but not require compensation (in the form of a specific distribution) ${ }^{47}$ The other would allow the courts to find no taking but award compensation anyway, as a matter of fairness. Note that, in the last class of cases, the required funds could come from the money banked in cases of taking/no specific distribution or from other revenues. Legislation might be required in order to give the judiciary a disbursing power.

In our view, the expanded set of four that results from the foregoing exercise helps illuminate and resolve many of the standard problems in takings law ${ }^{48}$ Here we focus on problems in Phillips.

\section{PHILLIPS ON REMAND}

The IOLTA program considered in Phillips is an example of government regulatory activities that impose small burdens on a large number of people, meaning that large sums are involved in the aggregate. We would usually think about cases of this sort in the following way: Since the programs in question impose only small per capita costs, there is little reason to require specific distributions, whether

\footnotetext{
${ }^{47}$ In these taking/no specific distribution cases, the constitutional requirement of "just compensation" may be met, in our view, through the use of a general distribution. See Heller \& Krier, Deterrence at 1007 (cited in note 42) (elaborating on this point).

${ }^{48}$ See id at $1005-13$ for discussion.
} 
for reasons of fairness or to ease demoralization costs. On the other hand, given the large total sums at stake, efficiency concerns might sometimes call for payment by the government as a general deterrent, or as a specific deterrent if the circumstances suggest exploitation of politically vulnerable groups. The high transaction costs of compensating large numbers of people, however, suggest any payment should take the form of a general distribution.

That is the general picture, but Phillips requires a more particular analysis, because IOLTA is what we call a "pooling" program, and a rather unusual one to boot.

\section{A. Pooling in General, and in IOLTA Programs}

Programs that create value by pooling are common but their analysis has been neglected, especially in connection with takings ${ }^{49}$ Physical or legal interests with little realizable value in individual ownership often gain value when pooled to a more useful scale, as where the government takes small fragments of interest from many clients to fund legal services that provide statewide public benefits.

1. How Pooling Generates Value.-Pooling programs yield added value in those circumstances where increasing marginal gains for decreasing costs) are realized as an additional person's assets are put into the pool and used along with the aggregate. In the case of IOLTA, increasing gains are relatively unimportant. They might be realized if banks pay higher rates of interest as the size of an account goes up, but any such effects will be modest because IOLTA funds are pooled only within each lawyer's office; the total size of any given account will remain relatively small and the rate of interest will thus be affected little, if at all.

Decreasing costs are another story. IOLTA programs have a comparative advantage in the generation and distribution of interest. Pooling makes productive those client funds that would not earn

${ }^{49}$ Generally, pooling cases arise when the government attempts to overcome a tragedy of the commons or of the anticommons by bundling fragments at the boundaries of private property. See Michael A. Heller, The Tragedy of the Anticommons: Property in the Transition from Marx to Markets, 111 Harv L Rev 621 (1998):

In a commons, by definition, multiple owners are each endowed with the [right] to use a given resource, and no one has the right to exclude another. When too many owners have such [rights] of use, the resource is prone to overuse-a tragedy of the commons. ... In an anticommons, ... multiple owners are each endowed with the right to exclude others from a scarce resource, and no one has an effective [right] of use. When there are too many owners holding rights of exclusion, the resource is prone to underuse-a tragedy of the anticommons.

Id at 623-24. 
interest on their own, ${ }^{50}$ and the manner of distributing these earnings-to a single agency rather than multiple clients-avoids the costs of keeping individualized records and making individualized payments. The resulting reduction in accounting expenses for tax and other purposes turns out to be very substantial. ${ }^{51}$

The Court in Phillips was very much mistaken when it said of IOLTA programs that "the State does nothing to create value." ${ }^{152}$ To see the point, take any situation where it would cost a lawyer more to distribute client interest (to the client) than the amount of that interest itself. If instead the lawyer pools all client funds into a single account and then makes a distribution to a single recipient (and that is how IOLTA works), the costs of generating and distributing the interest will usually be far less than the total interest earned. ${ }^{53}$ The Figure below illustrates the marginal effect of adding each new member to a pool, and the cumulative totals as the pool grows.
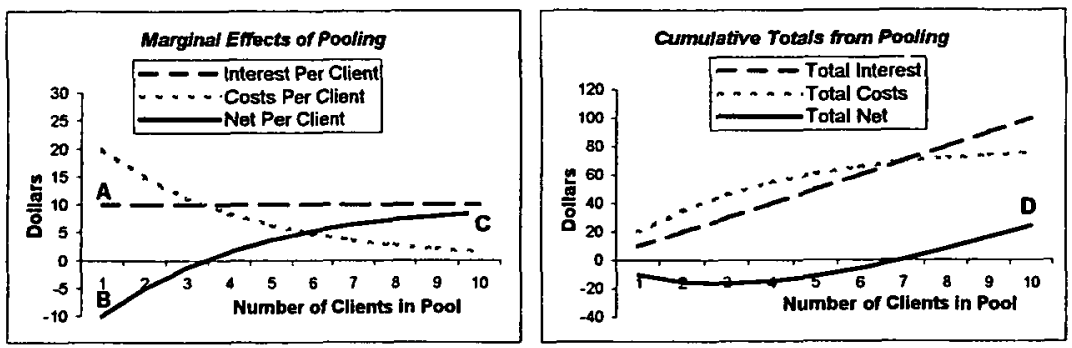

Figure: Marginal and Cumulative Values from Pooling ${ }^{54}$

${ }^{50}$ See note 8 above (discussing limitation of IOLTA programs to nominal and short-term client funds).

${ }^{51}$ See ABA Task Force and Advisory Board on Interest on Lawyer Trust Accounts, Report to the Board of Governors, 22-24 (July 1982)(detailing cost savings from pooling in the generation and distribution of interest earned on client funds).

${ }^{52}$ Phillips, $118 \mathrm{~S} \mathrm{Ct}$ at 1933 . As an aside, our argument does not require determining whether the state creates the value by pooling, or whether the value is an artifact of the background regulatory or technological structure.

${ }^{53}$ Nevertheless, Phillips is odd as a pooling case. States can generate scale efficiencies more easily than can individual clients, but IOLTA is not necessarily the best way of doing this. Just as IOLTA programs shifted $\$ 100$ million in interest to states, so the states could have collected the same amount using targeted taxes on banks, lawyers, or clients, or on other consumers of the public goods that the legal system provides its users. Depending on the costs of these alternative methods of collecting and redistributing funds for legal services, IOLTA programs may or may not be the most efficient approach.

${ }^{54}$ The Figure shows how pooling can generate value, but the underlying numbers are merely illustrative and not drawn from any specific IOLTA program. As an aside, the Figure can be easily generalized. Regulatory schemes that exploit scale economies 
2. The Interesting Numbers for Takings Analysis.-The majority in Phillips fixed its attention on Point $A$ in the Figure, the gross interest earned by any given client's principal. The dissenters, on the other hand, thought that if any interest mattered, it was the negative amount indicated by Point $B$, negative because there would be no net interest to distribute in the unpooled case.

In our view, neither of these numbers matter near as much as two other numbers that all the opinions in Phillips ignored. The first of these, Point $C$, is the net amount of interest that clients could withhold from IOLTA programs if given the option to do so (by stating, for example, that their funds were not to go into IOLTA accounts). ${ }^{55}$ No doubt it was $C$ that Justice Breyer had in mind when he asserted that the "most Texas law here could have taken from the client is . . the client's right to keep the client's principal sterile, a right to prevent the principal from being put to productive use by others." ${ }^{156}$ The observation is incorrect. A client option to deny $C$ to an IOLTA program would not render the client's funds sterile; they would remain productive, but the interest they produced would go to depository banks. In this sense, IOLTA programs simply redistribute wealth from banks to organizations that provide legal services for low-income people.

Point $D$ is another important number. It signifies the total net interest earned on the funds pooled in IOLTA accounts. The majority in Phillips deferred consideration of $D .{ }^{57}$ Justices Souter and Breyer, who did consider the value it represented, concluded that the amounts were attributable to the government /and hence not taken

will usually impose non-zero monetary harm on a number of people; each individual's burden shifts the marginal cost curve upward but does not affect its shape. The more each individual is harmed, the larger the pool necessary before cumulative benefits exceed total costs; at the extreme, per capita harms can be so high that the program in question will be inefficient no matter how large the pool of contributors becomes. At the same time, though, some regulatory programs may yield marginal benefits that increase at a faster rate than they do in, say, IOLTA programs. For example, the value of government provision of some goods may benefit from network effects, in which "the utility that a user derives from consumption of a good increases with the number of other agents consuming the good." See Michael L. Katz \& Carl Shapiro, Network Externalities, Competition, and Compatibility, 75 Am Econ Rev 424, 424 (1985) (defining network effects).

${ }^{55}$ This discussion pertains to mandatory IOLTA programs only. If lawyers can opt out, as many states now allow, see text accompanying note 9 above, then clients could indirectly opt-out by choosing a non-participating lawyer. Voluntary and optout programs involve giving, not taking; with respect to them, just compensation is irrelevant.

${ }^{56}$ Phillips, $118 \mathrm{~S} \mathrm{Ct}$ at 1938 (Breyer, J, dissenting).

${ }^{57}$ Id at 1934 (deferring taking and just compensation issues). 
away from anyone else).$^{58}$ We would think about distributing $D$ in ways that might better serve the underlying purposes of the Takings Clause. There could be forms of general distribution, for example, that gave clients a voice in determining how interest from their principal is used.

In short, conventional takings analysis identifies $A$ (gross interest) and $B$ (net interest) as the amounts that matter. Concerns with deterrence and distribution, on the other hand, shift attention to $C$ and $D$, thereby identifying the opt-out and client-voice alternatives discussed above.

\section{B. Deterrence and Distribution in Phillips}

Phillips is far from transparent to us. The path taken by all the justices in the case resulted in, among other things, a conventional factual record that is inadequate for our unconventional purposes. On the deterrence side, we need to know if IOLTA programs are likely to be so inefficient or oppressive that requiring the government to pay damages will act as a salutary check. To evaluate distribution questions we need more nuanced information regarding the plaintiffs' fairness claims and options for redressing them. We offer some initial speculations in the absence of a more developed record.

There is little doubt that pooling programs in general can give rise to concerns about inefficiency and the need for general deterrence, but we think the particular method of pooling used in IOLTA programs ends up passing muster. The programs do generate value, and at no actual financial expense to anyone but banks (which were getting a bit of a windfall in the first place). There is little monetary burden, per capita and total, and thus little reason to worry about general deterrence. As for specific deterrence, it is hard to see that IOLTA programs exploit any politically vulnerable groups (such as clients depositing funds). The programs might not be the most efficient way to provide low-income legal services, but they do not seem terribly wasteful either.

Fairness is another matter. IOLTA programs compromise the expressive and liberty interests of depositing clients, but conventional takings analysis is not very responsive to these concerns. ${ }^{59}$

\footnotetext{
${ }^{58}$ Justice Souter noted that courts would "measure any required compensation by the claimant's loss, not by the government's (or the public's) gain." Id at 1936 (Souter, J, dissenting). And, by analogy from land valuation cases, Justice Breyer noted that "the government must pay the current value of condemned land, not the added value that a highway it builds on the property itself creates." Id at 1939 (Breyer, J, dissenting).

${ }^{59}$ See note 11 above (discussing the plaintiff's First Amendment concerns).
} 
The majority in Phillips, for example, focused on monetary injuries that were trivial at best, yet ignored the denial of voice that motivated the case in the first place. As we mentioned in our earlier discussion of conceptual severance, the majority separated principal from interest, then considered the interest as a tangible thing that might have been taken; putting the principal to the service of IOLTA programs, on the other hand, was "at most" a regulation of the "use of property," and thus almost surely constitutional. ${ }^{60}$ Ironically, though, taking their interest actually hurts clients not at all, whereas conscripting their principal offends them a lot.

Our view, in sum, is this. If justice requires it, courts should be allowed to make general distributions that give clients a voice in the use of IOLTA funds, or to permit clients or their lawyers to opt out of the programs altogether. ${ }^{61}$ All in all, however, we do not see IOLTA programs as utterly inferior to alternative means of funding low-income legal services, such as a tax on clients or lawyers, so we are inclined to think that such moves are unnecessary. Perhaps fairness concerns would receive a more sympathetic hearing in a First Amendment tribunal than they do in our Takings Clause court.

\section{CONCLUSION}

The Phillips case is more interesting for what it provokes than for what it provides. The debates among the justices about the meaning of private property, argued in terms of contextual and conceptual severance, are unlikely to prove fruitful. Formalistic parsing of the Takings Clause, whether word-by-word or as an integrated whole, tells us little about how to harmonize the competing values at stake in modern regulatory programs. A better approach is to think in terms of the underlying purposes of just compensation, and to see that efficiency and justice are best served by uncoupling matters and methods of deterrence from matters and methods of distribution.

${ }^{60}$ Phillips, $118 \mathrm{~S} \mathrm{Ct}$ at 1930 . See text accompanying notes $36-37$ above.

${ }_{61}$ Though the tax treatment of client-voice and opt-out options would differ, takings analysis should not be tied to such concerns. With client-voice, the Internal Revenue Service would probably impute IOLTA interest to clients as income; with opt-out, there would be no imputed income. Phillips, $118 \mathrm{~S} \mathrm{Ct}$ at 1933 (citing the relevant IRS interpretations). 